\title{
From Song to Visual Art: Exploring Sehnsucht in the lived experiences of visual artists
}

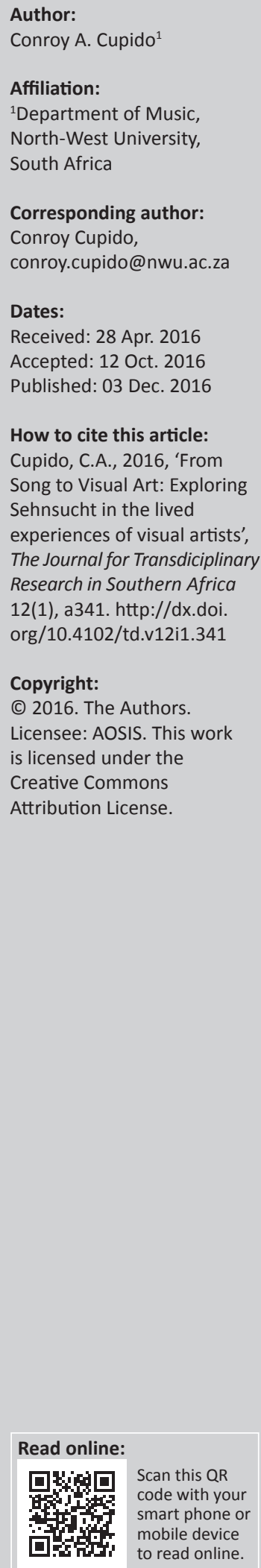

This article explored the experiences shared by four artists during their processes of creating an art work which represented a specific art song or Lied. During 2015, South African artists Marna de Wet, Kevin du Plessis, Jean Lampen and Eljana van der Merwe collaborated with the pianist Tinus Botha and baritone Conroy Cupido. The essence of the poetry and music of Vaughan Williams, Quilter, Schumann, Strauss and Brahms presented in this project conveyed a feeling known as Sehnsucht. The purpose of this article was to understand the experiences of these artists during their creative processes. Their processes entailed ascribing meaning and communicating their interpretation of the elements of Sehnsucht from the music and poetry to visual art. This was achieved through interpretative phenomenological analysis. The artists used various media including, charcoal on paper, oil paint on sourced objects, oil on canvas and photography to portray their interpretations. Through their artistic processes, the artists uncovered melancholy, Wanderlust, homo-eroticism, longing and the desire for love in the music and poetry. One of the artists discovered how her own concept of idealised love had evolved through her artistic process. The artists used both music and narrative content to visualise Sehnsucht; however, due to the non-referential nature of music, the artists were not always able to verbalise how the music influenced their work. The article includes images of some of the art works.

\section{Introduction}

Gertrude Stein once stated that 'A writer should write with his eyes, and a painter paint with his ears' (Rogers \& Rogers 1985:42). The relationship between proponents and creators of visual art, music and poetry is so clearly connected that it is not surprising how the popularity of transdisciplinary collaboration has grown. While it is unclear exactly when this kind of collaboration began, research has been conducted on a multidisciplinary approach to music as early as the 19th century (Adler 1885).

While it has been argued that the similarities between the mediums of visual art and music may not at first be evident, artists and musicians are increasingly overcoming boundaries set in place by the constraints of each medium:

Music is also about the passage of time whereas paintings and most other works of visual art convey their content in a single, all-at-once eternally present moment. Paintings are singularities, unique and un-reproducible physical commodities. Music, on the other hand, is intangible ephemera [...] today, the worlds of music and painting continue to intertwine as more and more multi-media work gets created. A piece of music inspired by a painting or a series of paintings is a commonplace event on a concert program. And, as artists continue to reject the Aristotelian notion of one artist making one type of art, there is also a lot of work which combines aural and visual elements into a unique whole. (Oteri 2005)

This article explores the experiences shared by four South African artists, Marna de Wet, Kevin du Plessis, Jean Lampen and Eljana van der Merwe, during their processes of creating an art work representing a specific art song or Lied. The German word Lied has been accepted since the 15th century to describe what is considered as western art song (Orrey \& Warrack n.d.). During 2015 these artists collaborated with pianist Tinus Botha and I on a multimedia project (concert/ exhibition). When I approached the artists they were all resident in Potchefstroom, South Africa, and the musicians were both affiliated with North-West University. I was therefore the performer, researcher and responsible for the concept of this study. I also selected all the art songs presented to the artists.

I conceived the idea of creating a visual representation of the songs while planning a concert programme consisting of works by composers Antonin Dvorak, Robert Schumann, Richard 
Strauss, Johannes Brahms, ${ }^{1}$ Roger Quilter ${ }^{2}$ and Ralph Vaughan Williams. ${ }^{3}$ While I studied the poetry it became evident that there was an interlinking theme arousing my interest in the music. The poetry of Heyduk, Rückert, Heine, Hart, Hoffmann von Fallersleben, MacKay, F. Schumann, Stevenson, Lord Alfred Tennyson, von Gilm zu Rosenegg and Waller, enhanced by the music, seemed to encapsulate feelings of wanderlust, and unrequited and reciprocated love, longing and desire. The essence of these poems conveyed a feeling known as Sehnsucht. Sehnsucht is often defined as longing, yearning, nostalgia, craving or intensely missing someone or something, or as originating from an impassioned, wholehearted longing or yearning (das Sehnen) and addiction (die Sucht) (Kotter-Grühn, Wiest, Zurek \& Scheibe 2009:428)

The purpose of this article was to understand the experiences of these artists during their creative process. Their creative process entailed ascribing meaning and communicating their interpretation of the elements of Sehnsucht derived from the music and the poetry in creating visual art. This was achieved through an interpretative phenomenological analysis (IPA).

\section{Participants}

Four visual artists were chosen to represent the music and poetry in their own medium. Kevin du Plessis was the youngest among the artists. Besides art, his studies guaranteed him a firm foundation in the literary world, having completed a bachelor and post-graduate degree in language and English literature. During his studies, Kevin began to struggle with and discover his own identity, beyond society's constraints of what a hetero-normative, white Afrikaner male was supposed to be. His chosen medium of photography had previously allowed him to express his feelings of race in South Africa:

My work, 'Looking to see in colour', explores the continuing need for South Africans to engage socially and otherwise with different cultures, albeit a difficult process met with discomfort, and even disapproval. The title encompasses what the work is about: looking, seeing, and colour. Dealing with perceptions and projections, and a personal struggle in learning to be comfortable in situations that ought not to be uncomfortable, the work looks to engage the observer into its own observations.

Marna de Wet spent a great deal of her career as a freelance graphic designer. Her journey as an artist started in 2009 when she participated in a 'Salon' exhibition followed by her

\footnotetext{
1.The German lied flourished during the 19th century, while Schumann and Brahms were considered to be two of the masters of the genre (Orrey \& Warrack n.d.). Richard Strauss was not only an important proponent of the lied in the 20th century but also a major force behind the transformation in its compositional style (Gilliams \& Youmens n.d.). Dvorak's music was greatly influenced by Brahms and folk music in particular (Kennedy n.d.)

2.Quilter, a contemporary of Richard Strauss, came to prominence as a songwriter in 1901, when Denham Price performed the Four Songs of the Sea at the Crystal Palace. $\mathrm{He}$ associated with many poets and painters. He favoured Shakespeare, Herrick and Shelley, often setting their texts to music. 'His wistful lyricism was characterized by Shelley, often setting their texts to music. 'His wistful lyricism was ch
chromatic harmonies and highly vocal melodic lines' (Langfield n.d.).

3.Folk music proved to be a major influence in the music of Vaughan Williams as well as the revival of interest in English 16th -century composers (Kennedy n.d.).
}

first solo exhibition. In 2013 she visited the Cité Internationale des Arts in Paris, France, for two months where she had the opportunity to hone her skills and self-reflect upon her work. Marna mostly paints in oil and although she describes herself as not being a conceptual artist, she describes her paintings as 'very poetic and almost melancholic of nature with deep meaning and depth'.

\section{Eljana van der Merwe is a self-proclaimed Gypsy:}

'I have been on the road for the best part of my life. From my birth in Stella (in the North West Province of South Africa) nearly thirty-five years ago, my parents familiarized me with the gypsy way of life, always traveling across South Africa. My formative years were mostly spent in Klerksdorp, South Africa after which my adventurous spirit took over, leading me to explore all kinds of foreign destinations.'

Eljana has held fixed positions as an arts and Culture teacher, but in 2008 continued her travels from South Africa to Europe and Central America. During a 9-month stay in Mexico she donated two Nelson Mandela-themed murals to the community: '67 Colours of Mexico's Mural for Madiba' was done in cooperation with the students of the Universidad del Sur in Guerrero Mexico (UNISUR) and 'Espacio Cultural de Nelson Mandela' in Mexico City.

Jean Lampen specialises in water colours, sculpture and life drawings. She was the oldest artist in the group, and this was reflected in an extensive body of work reflecting her life experiences and years of acquired knowledge and skill. She has exhibited throughout South Africa as well as Mauritius and in Paris, France. She is a part-time lecturer at North-West University (Potchefstroom) in the School for Graphic Design and School for Creativity. She describes her work as 'mostly monochromatic using mainly pen and ink, charcoal or linocuts, and would like to complete a project adding layers and meaning to the work by combining the different media, as well as working with recycled materials'.

\section{Literature review}

This review is divided into three sections. Its aim was to uncover perspectives in the literature about (1) how Sehnsucht has previously been interpreted in music and art, (2) the influence of visual art on music compositions (to contextualise the significance and unique nature of the current study) and (3) the influence of music on visual artists.

\section{The occurrence of Sehnsucht in research}

What makes this article unique is the fact that no research has been done on the experiences of artists transferring elements of Sehnsucht found in music and poetry to visual art. Research on Sehnsucht has in fact been limited to music. What is understood as Sehnsucht in the literature is often identified in research on longing, desire and nostalgia. Several settings of Goethe's poem Nur wie die Sehnsucht kennt ${ }^{4}$ may be found in the music literature today where composers have captured 4.Only he who knows what yearning is (translation). 
the essence of Sehnsucht in the poetry. Doherty (2014) applies a semiotic analysis of the music and text of Schubert's Lied, Nur wer die Sehnsucht Kennt (D. 877, No. 1). He focuses on presentation, representation and interpretation in a pastoral context. Forbes (1972) argued that although Schubert's settings of Nur wer die Sehnsucht kennt were superb and fully conveyed the textual meaning, Zelter and Beethoven's settings were a truer reflection of what the poet (Goethe) had in mind. Other authors who have written about settings of this poem include Larsen (1969), McClain (1984), Olthafer (2006), Urmoneit (2002), Jung-Kaiser (2009) and Doherty (2013).

In her dissertation 'Unendliche Sehnsucht: The concept of longing in German Romantic narrative and song', Reichert (1994) examines the concept of Sehnsucht in German Romantic narrative and song, specifically tracing its emergence and programmatic use. She focuses on songs by Schubert and Schumann, and on writings by Johann Friedrich Reichardt, Wilhelm Heinrich Wackenroder, Ludwig Tieck and E.T.A. Hoffmann.

Canisius (1992) discusses the longing and unrest in Beethoven's music. Rummenhöller (1999) discusses the subject of love in the arts and how this subject is discussed pedagogically in the classroom, specifically describing how being in love can be seen as a motif found in music, literature and the fine arts. Malvano (2003) describes Schumann's use of musical motifs as a means to convey the Sehnsucht in the texts of the poets, specifically elements of remoteness and his fascination of the faraway world. Beller-McKenna (2010) discusses Sehnsucht and nostalgia in Beethoven's Lieder und Romanzen for women's chorus, Op. 44. Petrauskait (2012) describes nostalgia as an expression of longing in the Lithuanian music of the 20th century. In an empirical study of the listening experiences of 32 college students, Juslin et al. (2008) discovered that nostalgia/longing was one of the most frequent emotions identified by these students.

\section{Music from visual art}

During the last century the number of works reflecting a composer's integration of art and music increased significantly. Oteri (2005) summarises some of the most noteworthy examples of such composers ranging from Rachmaninov to Tan Dun. He mentions that composers from various backgrounds have used colour through instrumentation to depict tone combinations. Perhaps the most famous example of a composer depicting art sonically is Mussorgsky's Pictures at an Exhibition (1874) (Oteri 2005). The composition draws inspiration from 10 drawings and watercolours by his recently deceased friend, Victor Hartmann.

Another successful transference of art to music is Sondheim's Sunday in the Park with George. This Broadway musical was inspired by George Seurat's Sunday Afternoon on the Grand Jatte. Other composers influenced by art include Debussy, Schoenberg, Mikalojus Konstantinas Ciurlionis (who was both painter and composer), Gershwin and John Cage (Oteri 2005).

In his book, The music of painting: Music, modernism and the visual arts from the Romantics to John Cage, Peter Vergo (2010) extensively examines the correlation and relationship between artist and composer, and how their art works and compositions influenced each other. De Duve (2013) mentions how John Cage was influenced by Duchamp and the Dada avant-garde art movements of the 20th century. Jewanski (2011) discusses the influence of the visual arts on the compositions of Morten Feldman, specifically how John Cage's collaborative style was a trigger for his interaction with painting.

In her dissertation Wharton (1998) describes how Poulenc was also influenced by the visual arts. Poulenc himself mentions this in his Journal de mes mélodies, a volume of brief essays on each of his songs. Here he describes how art works or artists were associated with a particular song. Wharton mentions that he was influenced primarily by French artists as well as Spanish and Italian painters ranging over a period of 5 centuries.

\section{Visual art inspired by music}

It is clear that much research exists (as described above) on the influence of visual art on music compositions. To my knowledge far less research exists concerning visual artists who have been influenced by music (Western classical composers specifically). Manfred Mohr (2000) describes how the French composer Pierre Barbaud radically changed his artistic development to cultivate a more systematic, geometric form of expression. Gottdang (2006) describes how artists around 1850 could not reach a consensus on whether landscape paintings should draw inspiration from vocal or instrumental music. Only a few artists (Ludwig Richter, Friedrich Preller and Gabriel Max) were able to depict the influence of music in their landscape paintings. De Decker (1989) discusses the journey of Baudouin Oosterlynck from composer and performance artist to an artist mainly specialising in drawing and installation art. She also mentions John Cage's influence in this artist's life.

In 2015, Inala, a multidisciplinary performance piece featuring music, dance and art, was premiered at the Edinburgh International Festival. This singing ensemble was collaborated with classical composer Ella Spira and members of the Royal Ballet Company. This performance was themed 'abundance of goodwill' and was a fusion of Western and traditional South African culture (www.southafrica.info). While works like this continue to garner attention in South Africa, the works of William Kentridge remain some of the most notably documented. South African artist, William Kentridge, is well known for his multimedia works and collaboration. Inspired by Mozart's opera, Die Zauberflöte, his work, Learning the Flute (a 35- $\mathrm{mm}$ animated film transferred to video and projected on blackboard), was an attempt to 'find the visual language for the opera' (Auping et al. 2009:171). In his work, 
Black Box (a model theatre with drawings - charcoal on paper, mechanical puppets and 35-mm animated film transferred to video), Kentridge examines the 'political unconscious of The Magic Flute - at the damages of colonialism, which described its predations to itself as bringing enlightenment to the dark continent' (Auping et al. 2009:171).

Kentridge's attraction to the tradition of classical singing also includes German Lieder. From 11 to 13 March 2016 San Francisco Opera produced Kentridge's staging of Schubert's Winterreise. This production had previously appeared in 2014 in Aix and at the Lincoln Centre's White Light Festival. Matthias Goerne, baritone, and Markus Hinterhauser, pianist, performed Schubert's cycle, while Kentridge included artwork and 24 short films in the production (Mazzaro 2016:6).

\section{Methodology \\ Meeting with the artists}

I was aware of two prominent artists, Marna de Wet and Kevin du Plessis, in the Potchefstroom vicinity. Marna de Wet referred two other artists, Jean Lampen and Eljana van der Merwe, who were both members of the Potchefstroom Art Society. I wanted to use local artists to promote the talent in the area and because it was convenient and efficient to collaborate with artists in such a close proximity. After the artists agreed to participate in the project, they listened to the art songs, read the poetry and indicated which art songs they would like to express visually. They were requested to produce one art work depicting each song (a minimum of four songs each), and they were not limited to any specific medium. They were tasked with illustrating the elements of Sehnsucht as they experienced them in the music and poetry. Upon completion, the musicians presented a concert in Potchefstroom where images of the art works were displayed as each art song was performed. Separate gallery exhibitions were also presented in Potchefstroom and Pretoria (where the actual art works were on display). At these exhibitions visitors were able to look at the art while reading the poetry and listening to recordings (by Botha and Cupido) of the art songs provided alongside each work at a listening/reading station. The viewer/listener/reader therefore enjoyed a complete sensory experience of the music heard, the text and visual art.

\section{Study protocol}

The reason why I chose this qualitative research approach was because the key elements of IPA best suited the objectives of this study. These key elements are described by Reid et al. (2005:20) as follows:

- 'IPA aims to capture and explore the meanings that participants assign to their experiences.

- Participants are recruited because of their expertise in the phenomenon being explored.

- Analysis relies on the process of people making sense of the world and their experiences, firstly for the participant, and secondly for the analyst.
- A successful analysis is: interpretative (and thus subjective) so the results are not given the status of facts; transparent (grounded in example from the data) and plausible (to participants, co-analysts, supervisors, and general readers)'.

After completing the literature review, to my knowledge, no research has been done on the lived experiences of artists during their process of creating artworks depicting Sehnsucht found in art songs (both in the music and poetry). In fact, in this review, I did not encounter any significant IPA studies regarding visual art and music. Although semiotics features in this type of study and in the literature reviewed, it is not my intent to assign meaning to the works created by the artists. The artists rather themselves assign meaning through their interpretation of the text and music and as is the nature of IPA my role is to interpret their experiences within this interpretative paradigm. "This attempt by the research participant to make sense of what is happening to them takes us to IPA's second major theoretical axis. It is an interpretative endeavour and is therefore informed by hermeneutics, the theory of interpretation' (Smith, Flowers \& Larkin 2009:3).

Another characteristic of IPA is that these artists or participants were selected based on their expertise. A brief biographical description of each artist is given prior to each individual case. The main research question is: what did the creative process entail when transferring musical and narrative elements of Sehnsucht to the artists' chosen visual medium? Two sub-questions arose: (1) how did each individual artist find meaning in transferring the elements of Sehnsucht to art? (2) What were the shared commonalities and differences in their experiences during the creative process? My role as the researcher was to make sense of the experiential data obtained through semi-structured interviews and observations by coding and systematically analysing all the data. In doing so I could interpret the distinct or shared commonalities and differences in the experiences across the artists. The artists gave their informed consent before the interviews took place, and they allowed their names to be used for the purposes of this article. The results were validated by member checking. My interpretations of these shared lived experiences will be discussed later in the article.

Leman (2010:85) states that 'a motivation for developing transdisciplinarity in music research may be grounded in ethical principles that foster progress and well-being of society'. He also highlights the need for more research to be done and says that 'the transdisciplinary nature of music research may be a strong asset to the development of a new type of creative music industry' (2010:65). With the notable exception of work done on Kentridge by Auping et al. (2009), the study of the phenomenon of using music with text as inspiration for visual creation is limited. Byrnes (2007) describes how visual artists were influenced by the dissonance and abstraction of the compositions of 20thcentury composers: 
To visual artists moving beyond formal representation, music provided a guide because they considered it already to be in a state of pure abstraction. As Frances Guy, the curator of 'EyeMusic' puts it: 'Its freedom from representation or narrative content, and its ability to communicate directly with the soul and evoke an emotional response, was an inspiration for artists who wished to do the same'. (p. 43)

This provided a theoretical framework with an interpretive paradigm to explore how the artists in this study found their 'visual language' while having to convey Sehnsucht found in both text and music. This IPA therefore contributes to need for new research as mentioned by Leman (2010). Each artist had the freedom to internalise the poetry and music subjectively. Their interpretations may at times be superimposed on the text and music based on their own previous lived experiences. The artists identified Sehnsucht in the poetry and music as the following four main themes respectively:

- Sehnsucht as homoeroticism

- nostalgia and the yearning for requited love

- the interpretation of love after divorce

- connecting Wanderlust to emotionally linked sourced objects.

\section{Exploring Sehnsucht as homoeroticism through the music of Strauss and Brahms}

Kevin du Plessis selected the following four art songs by Brahms and Strauss:
Allerseelen Op. 10, No. 8
R. Strauss (1864-1949)
Cäcilie Op. 27, No. 2
Morgen Op. 27, No.4
Dein blaues Auge Op.59 No.8
J. Brahms (1833-1897)

Kevin extrapolated the elements of Sehnsucht in his art works through the medium of photography. He expresses his synthesis of human experiences in his works through his artistic philosophy:

\footnotetext{
I see art as a tangible visual representation of human experiences. For it to be true and meaningful I believe that art should emerge and be formed by the things that occupy the mind and human condition. Art is a strong form of communication that may vary from powerful but difficult to interpret to relatable and aesthetically pleasing. It is complex and in a constant state of change, like the human spirit.
}

Kevin listened repeatedly to the music and poetry of the art songs until he found a place of inspiration within himself from which visual material started to emerge. Kevin's process and experiences differed significantly from that of the other artists, as he was the model for his photographs and he also played the particular art song on repeat while he was busy with that specific photo shoot. Even though Kevin was the model for his own images, he does not view these as self-portraits. He managed to capture several emotions in different images, incorporating various aspects of Sehnsucht depending on the moment in time when he shot the photograph and at which point the recording track was being played:

Listening to the music on repeat all the way through the shooting process, I used myself as model, struggling to capture images whilst running back and forth between the set up scenes and the camera itself. By doing this the performances in front of the lens were affected by the tone in the songs that were being sounded throughout the house. I kept reading and rereading the translations of the poems until I felt like I related to the narrators, then re-enacting to what they are describing.

Kevin listened to recordings of Morgen and Cäcilie with orchestral accompaniment ${ }^{5}$ which I presented him in addition to my own recordings with the piano accompaniment. I wanted to see if the colour and emotional intensity provided by the orchestra would contribute to his lived experiences of the works. When he describes tone, he distinguished the difference in colour and texture which the orchestra provided the piano accompaniment alternative.

The elements of Sehnsucht which Kevin identified and wanted to incorporate in his visual representations included 'longing, love, broken-heartedness, and yearning for things past or out of reach'. To unify these elements visually, Kevin used a house with a single (lonely) occupant as a metaphor in all four works:

The house itself is meant to represent longing; in a post-apartheid South African small town the house has gone through many stages of its existence. It was once a regular family dwelling, after which it was a guesthouse which eventually closed as it started to deteriorate and was then rented out as cheap accommodation to students. It was known as Provence while it functioned as a guest house.

Kevin also associated emotional meaning with the architecture and structure of the house and items found inside:

The owners had tried to make the house seem like it was somewhere in Europe and used bits and pieces from European culture to create a romantic atmosphere for guests to experience. I associated this with the parts of the songs where the narrator yearns for that which is out of reach, causing the pain so evident in the performance of the songs. In the same way the house yearns for a past or a place or a time that is out of reach.

Kevin used a bedroom in the house to depict Strauss's Cäcilie (Figure 1). Heinrich Hart's text overflows with emotion capturing the yearning for a specific person, possibly in a state of unrequited love:

If you only knew what it's like to dream of burning kisses, of wandering and resting with one's beloved, eye turned to eye, and cuddling and chatting - if you only knew, you would incline your heart to $m e !^{6}$

5.Jessye Norman. Richard Strauss: Four Last Songs; 6 Orchestral Songs (recording): Decca, 1983.

6.English translation by Emily Ezust (www.lieder.net: accessed 02/01/2015). 


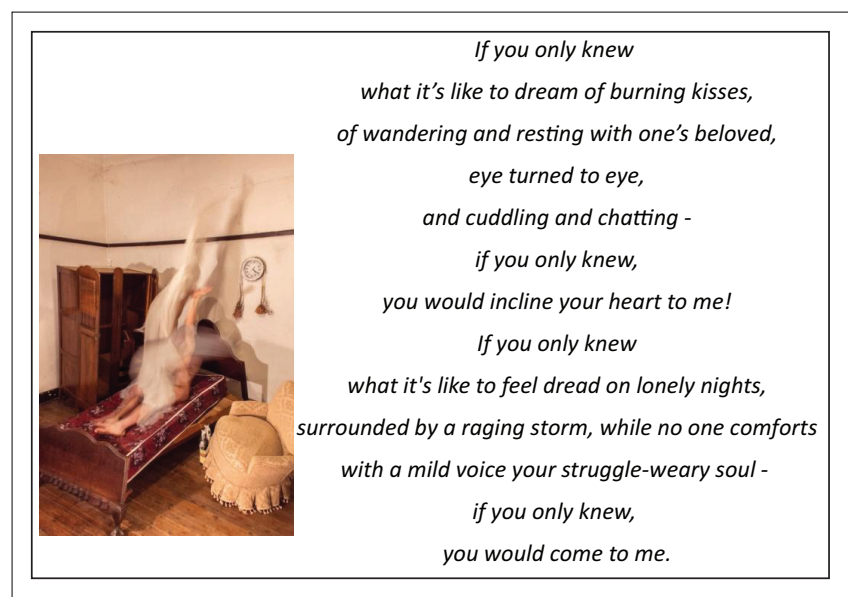

Source: Kevin du Plessis

FIGURE 1: Cäcilie: 'The Bedroom'.

Kevin wanted to subtly reference Van Gogh's 'The Bedroom' in this piece: 'The sad story of his life as an artist is meant to add to the sadness and the longing for the glorious love of the narrator in this poem'. Kevin used the significance of the bedroom and the movement of the furniture to capture the feeling of longing and to add meaning to his experience:

The bedroom is also a place of love-making; however, in this case the absence of the person being desired creates an especially empty lonely place. With the furniture moving in and suffocating the speaker, the empty bedroom is a personal place of imprisonment filled with the hurtful nature of unfulfilled possibilities and desires.

Although the listener never knows whether the narrator eventually captures the heart of his beloved in this declaration of love, Strauss' music suggests hope and happiness in the final verse of Hart's text:

Likewise, the sunny return to the major mode at the end of the second text strophe predicts the expansion of the imagery of the third strophe into ideal realms, to which one travels in a blaze of light to the heights of the blessed creation. The ascending scalar figures in the piano postlude confirm this upward sweep. (Hambrick n.d.)

A striking feature of this image is the sheet being thrown up in the air which Kevin equates to Hart's portrayal of hope in the final verses of the poem:

The song moves into a more dramatic space closer to the end, becoming more hopeful and dreamy, showing that the narrator is not completely without hope since he is still dreaming of how glorious it could all be; I tried capturing this by means of the spontaneous play with the sheets on the bed being thrown up into the air. It is a moment of hope and excitement at the narrow possibility of his desires being fulfilled.

As the final Lied of Strauss's Opus 10, Allerseelen, ${ }^{7}$ set to a text by Hermann von Gilm, depicts the longing of a lover who has since passed. In his work 'The Door' (Figure 2) Kevin used a door and hallway of the house to depict this nostalgia and yearning for the person who had died:

7.Hambrick (n.d.) writes that: Strauss's largely syila bic vocal declamation and frequen repetition of pitches underscore the nostalgic simplicity of the text. The waves of graceful arpeggiated sweeps in the piano accompaniment throughout the song reinforce Gilm's interpretation of All Souls' Day, suggesting the yearning for the ideal springtime place where love is innocent and lovers are united in otherworldly bliss.

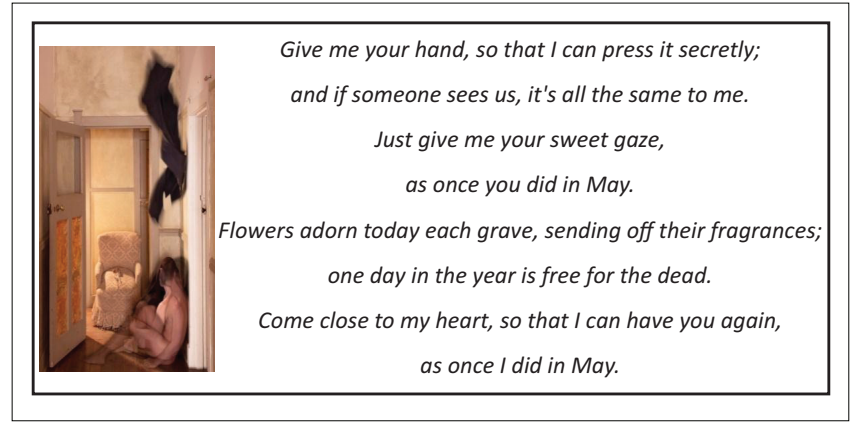

Source: Kevin du Plessis

FIGURE 2: Allerseelen: 'The Door'.

I focused on the door in this part of the house, although the hallway also plays a part. Since a person does not normally sit in a hallway it was meant to suggest that the subject had fallen to the ground in a sudden fit of sadness and extreme longing.

Although Kevin recognised loneliness in all four art songs to varying degrees, he experienced it most in the text of von Gilm. To make sure that he captured the essence of this loneliness, Kevin was alone in the house whenever he captured his images for all four works. In the final lines of the poem von Gilm writes: 'One day in the year is free for the dead. Come close to my heart, so that I can have you again, as once I did in May'. ${ }^{8}$ Kevin once again used movement (of the person and the sheet) and also colour to depict loss and yearning:

By holding himself up in a ball and collapsing to the floor, the movement of the person is meant to suggest extreme mourning as well as trying to reach out and hold on to the figure of his lover. Of course the lover is no longer there and instead the person grasps at shadows (depicted by wispy figures made through long lens exposures). The black material is a symbol of death as it covers the face of one of the captured instances of the figure sitting on the floor and in part also hovers over his life like a black cloud on his spiritual well-being. Even though it is out of place in this instance, the material throughout the series is referencing sheets on a 'lovers' bed.

Kevin uses the door to illustrate the barrier or separation between the subject and his lover. When one examines the image, one sees that the hallway is covered in shadows while light fills up the space beyond the threshold. He ascribes this light not only to the afterlife where the deceased lover now resides, but also to memories of their time together:

The door, then, is the separation between the two lovers. The deceased has passed the threshold whilst his lover remains on the side of the living. The world of the mourner is in darkness (the hallway), whilst the light radiates from the other side of the threshold. The light touches the mourner from the other side as his memories of time spent in their relationship lights up his mind from beyond the grave.

Similarly to 'The Bedroom', Kevin used a chair positioned in a forward angle with flowers on its seat. These elements represent a physical manifestation of the lover who has been 8.Translation by Emily Ezust (www.lieder.net: accessed on 02/01/2015). 
left behind waiting for death and the deceased who also leaves signs that he is always present, even after death:

The empty chair is what the speaker, as I interpreted my feelings on the subject, sees as his empty seat that awaits him until such time as they will be reunited. The flowers on the chair, dried out, are a sign from his deceased lover that he is receiving his gifts and love even beyond the physical world. Of course these elements can be read simply as visions in the mourner's own mind during his fits of longing and heartbreak.

As previously mentioned, the artists superimposed their own experiences onto the text and music. Their experiences do not necessarily reflect what the poet or composer had intended. Experiencing Sehnsucht is best described by C.S. Lewis in The Weight of Glory:

We cannot tell it because it is a desire for something that has never actually appeared in our experience $[\ldots]$ these things - the beauty, the memory of our own past - are good images of what we really desire; but if they are mistaken for the thing itself they turn into dumb idols, breaking the hearts of their worshippers. For they are not the thing itself; they are only the scent of a flower we have not found, the echo of a tune we have not heard, news from a country we have never yet visited. (Lewis 1949 [revised 1980]:29-31)

While creating visual representations of the poetry and music, Kevin could not prevent his own personal experiences of love to influence his work. He had recently been on a path of self-discovery where he began to accept aspects of his sexuality:

I must admit that bits of my own challenges in life did creep through. Having come out of the proverbial closet at the time and starting to identify as a homosexual male, the transposed long exposure images have definite homo-erotic effects. I had, without realizing it at first, viewed these extreme emotions in the songs not as hetero-normative messages, but I saw them through my own view-point as male-on-male love stories.

All four of Kevin's depictions are open to homoerotic interpretations, but they are most prevalent in Brahms's Dein blaues Auge (Figure 3) and Strauss' Morgen (Figure 4).

Brahms's musical setting of Klaus Groth's text depicts the yearning for relief after the subject had been severely hurt by a former lover. He seeks comfort in the blue eyes of his current paramour. Kevin uses the floor to suggest a place where the subject and the previous lover had been intimate or where the current lovers find solace in each other's arms:

Being on the floor of the house in this work, and maybe I was the only one to ever really know this, the scene is actually being shot on a spot where an intensely passionate night or sexual encounter may have occurred between the two lovers. The narrator heads back to that spot on the floor in an attempt to capture that moment of pure lust and joy.

The bed sheets are used once again in the image. 'The sheets here are grey, representing the cool headedness of the whole affair, but it also symbolises the lack of empathy or love from the blue-eyed lover'. Although the blue-eyed lover never speaks in the poem, it was interesting to observe Kevin's

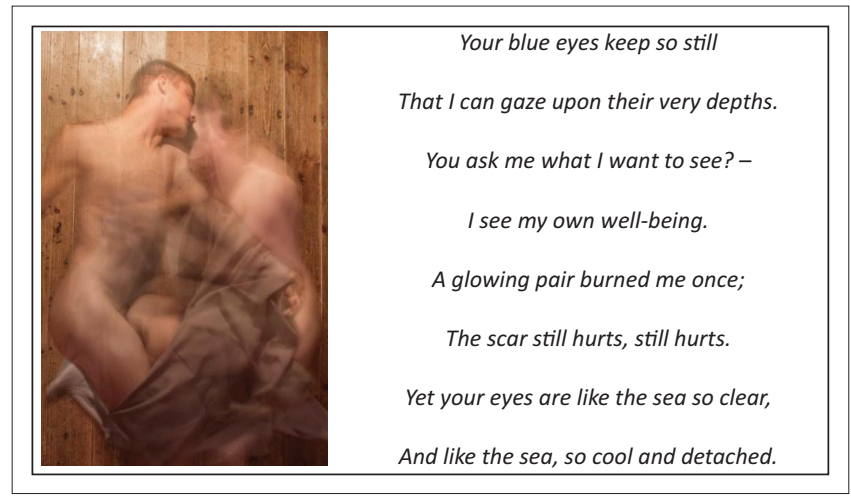

Source: Kevin du Plessis

FIGURE 3: Dein blaues Auge: 'The Floor'.

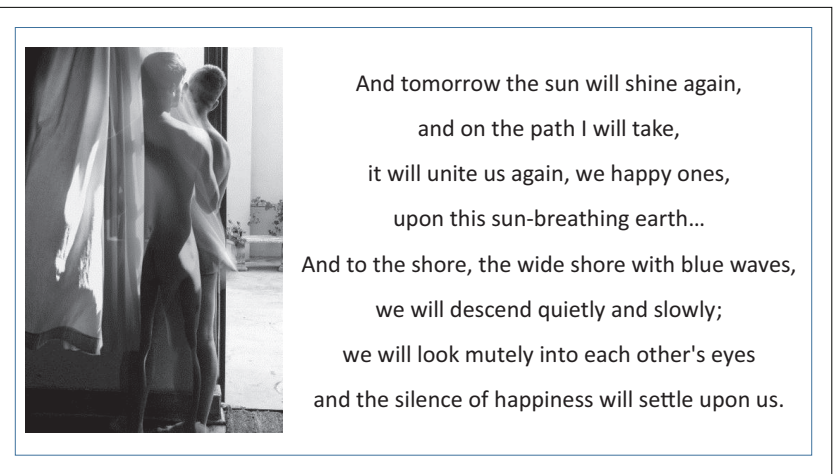

Source: Kevin du Plessis

FIGURE 4: Morgen: 'The Window'.

experience of the lover as 'lacking empathy'. During the interview, it was evident that Kevin's past experiences of love during his coming-out process came into play. 'The blueeyed lover on the right is distinctly wispier, like many beautiful people can be: hard to tie down'. He also mentions Oskar Kokoshka's 'The Bride of the Wind'9 as a subtle point of reference to 'the Floor'.

Kevin's visual representation of Strauss's Morgen is different from the other three works in many ways. While the other songs portray stronger feelings of longing and hurt, Kevin experienced Morgen as optimistic. This optimism is clear in the beginning and in the final lines of John Henry MacKay's text:

And tomorrow the sun will shine again and on the way that I will go, she will again unite us, the happy ones [...] silently we will look in each other's eyes and upon us will sink the mute silence of happiness. ${ }^{10}$

Kevin uses the window of the house, specifically what is beyond the window, to illustrate optimism and the possibility of happiness and new beginnings. He states that:

it is the one work that is optimistic, even though it is still a song of longing, but longing with the added ingredient of hope. Amidst the other songs I saw it as a moment of hope whilst looking out of the window and feeling the wind and sunshine, a

9.This work is a self-portrait depicting Oscar Kokoshka next to his lover, Alma Mahler (Johnson 2009).

10.Translation by Emily Ezust (www.lieder.net: accessed on 02/01/2015). 
moment that love seems just about within reach and where the longing for a person is not heavy but light and beautiful. In the metaphorical house, 'The Window' looks out towards new and fresh possibilities. The slow and peaceful melody of the song generates nostalgia and positive thinking. For me, an inherent sadness remains in the work since we will never know if the 'tomorrow' being sung about here will ever come for the person/ people in these songs and this series of artworks.

Besides grey scale, Kevin also uses natural light to depict optimism as opposed the artificial light used in the other three works:

this is meant to emphasise inner struggle/inside the bowels of the house and to highlight the moment of joy and positivity, the moment where love is an optimistic possibility and not a sad retrospective or yearning.

\section{Nostalgia for a lost home and the desire to love and to be loved in return}

After listening to a selection of art songs sung by Bryn Terfel, ${ }^{11}$ artist Marna de Wet chose to create a visualisation (oil on board) of the following four English art songs:

- Let Beauty Awake

R. Vaughan Williams (1872-1958)

- Whither Must I Wander?

- Now Sleeps The Crimson Petal Op. 3 No. 2 R. Quilter (1877-1953)

- Go, Lovely Rose Op. 24 No. 3

In her approach to this project Marna stated that she definitely did not only want to create a literal representation of the text and music, but rather an emotion or feeling for the viewer. She describes her work as generally poetic in nature, full of emotion and depth with undertones of melancholy. She mentioned that she had been previously inspired by the elements of Sehnsucht in her own work, but did not notice this specifically as Sehnsucht until working on this project.

Before beginning this project, I presented all the artists with a recording of the various art songs as well as the text of the poems. After listening to all the songs Marna de Wet (Figure 5) was instantly drawn to the songs of Ralph Vaughan Williams and Roger Quilter. She connected immediately to certain

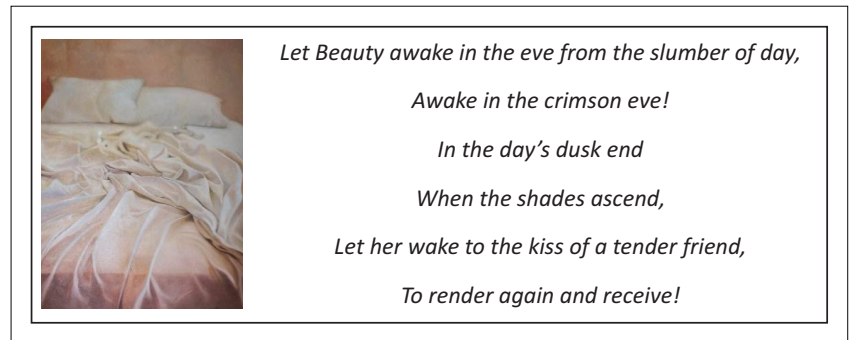

Source: Marna de Wet

FIGURE 5: Let Beauty Awake: 'The Bed'. words in the poems which together with the music evoked feelings of nostalgia:

The music spoke to me and I knew that I could create something based on it. I allowed the music to guide my emotions to the feeling I wanted to recreate in my art. I extracted a word or sentence with which I connected and combined it with the emotion in order to illustrate the elements of Sehnsucht.

Marna's process also involved identifying words or phrases from Robert Louis Stevenson's poem and expanding upon them by associating them with other words, imagery, emotions or concepts. From the art song, 'Let Beauty Awake', which is the second song from Vaughan Williams's cycle Songs of Travel, Marna associated the following words and ideas with Sehnsucht: 'morn', 'fresh', 'awaken', 'slumber of day', 'day/night', 'nature as a person', 'love which awakens'. These words and associations culminated in the idea of the narrator's love (Beauty) or love itself which awakens within the narrator.

The conceptualisation of love as these two embodiments is also described in the literature as follows. Larson (2001:31) identifies 'Beauty' as 'the narrator's impression of nature as the embodiment of Beauty'. Hallmark rather describes 'Beauty' as 'the dawn of romance in the vagabond's life or [it can be] interpreted as the artist's awakening to his calling' (Hallmark 2003:134).

Marna's 'light-bulb moment' (as she describes it) was the visualisation of a luxurious bed which had already been slept in. When the viewer sees the bed, it is already empty, perhaps suggesting the longing for a love which the narrator never truly receives (Figure 6).

'Whither must I wander? has a homely simplicity, appropriate to the poet's images of childhood and the security of home and family which are now long in the past, never to return' (Burn 2003). It was this security of home that evoked Marna's interest. She indicated that the following words stood out from Stevenson's poem: 'childhood', 'open door' and 'moorland'. Marna was not familiar with the term 'moorland' and after some research found the following definition as she described in her interview: 'a type of habitat found in upland areas or uncultivated hill land'. Immediately 'habitat' triggered Marna's interpretation of Sehnsucht in the poetry. 'Habitat represented the longing for the place where you grew up. Man is always in search of or trying to create a habitat where he feels safe'.

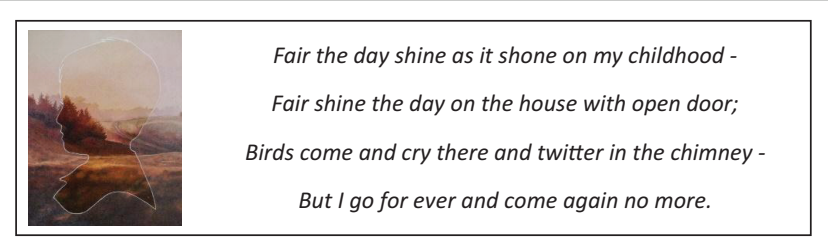

Source: Marna de Wet

FIGURE 6: Whither Must I Wander? 'The Boy'. 
This longing is also captured by Clark (2014) who writes:

In this poem, the Vagabond has either returned to his childhood home or he is remembering what it was like to live there. The comparisons between his former life and his current one are stark indeed, for now he is experiencing the hunger and the cold and, since he left his love behind, he is also experiencing these hardships alone. His childhood home, by contrast, was always warm, lit with a fire, and full of friends. These memories are happy ones, but memories are all they are. Just as the Vagabond has left home, so has everyone he used to associate with his home. Now it is an empty house and the Vagabond will never return to the life he had as a child. (p. 179)

She searched for images of moorlands until she found one where the colours conveyed the emotion and longing she interpreted in the text and music. After painting the landscape, she superimposed the silhouette of a boy over it. To Marna the silhouette was reminiscent of portraits of children found in family homes during Victorian times. 'By making the silhouette transparent, the landscape became part of the child, illustrating the desire or longing for this habitat or safe place' (Figure 7).

Marna's deep-rooted connection to melancholia is one of the reasons that the poetry of Lord Alfred Tennyson appealed to her. Lord Tennyson himself spent seven months in a 'hydropathic' establishment in an attempt to cure his melancholy (Tennyson n.d.). From the text Marna identified the following words and word associations: 'a road to somewhere', 'a road to your heart', 'to be lost', 'be lost in me', 'to lose yourself in someone' (Figure 8).

After listening to the music and reading the poem, Marna described her experience of Sehnsucht in the art song as an emotional journey rather than erotic love-making:

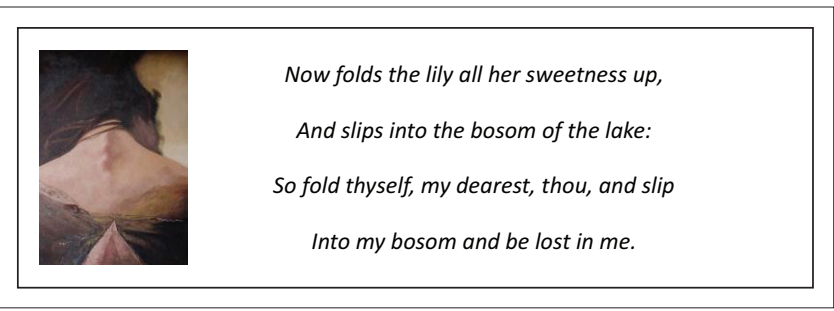

Source: Marna de Wet

FIGURE 7: Now Sleeps the Crimson Petal: 'The Journey'.

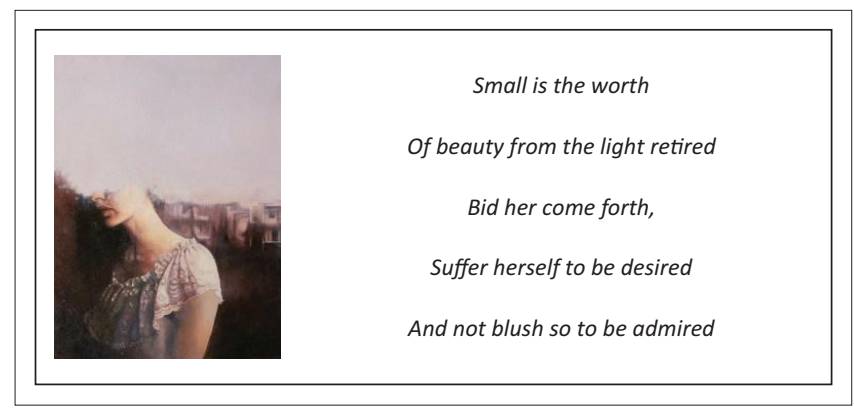

Source: Marna de Wet

FIGURE 8: Go, Lovely Rose! 'Reflection'.
The feeling that I wanted to visualise was the desire to be able to completely give yourself to someone that you end up losing yourself in them. I also wanted to illustrate the journey that one would embark on in order to do so. This would be a metaphorical road that you and your significant other would travel upon.

Marna describes the experience of making a visual depiction for this art song as the most difficult to accomplish. A rose would be the most logical representation as this is what the poet, Edmund Waller, used as a metaphor to describe the subject. 'The rose serves as a metaphor for an attractive woman. The speaker hopes that the lesson provided by the rose will prompt the maiden to yield to his advances' (Miller 2002:1).

The Sehnsucht identified in this art song is the desire to have one's love accepted while there is still time to do so. This may require the object of one's affection to resolve issues which may cause pain in order to accept this love (Miller 2000):

The poem ends as it began, with an appeal to one who is 'sweet and fair'. The woman must accept his advances while she can. Time is short, as he reiterates in the closing couplet: 'How small a part of time they share/that are so wondrous sweet and fair'. The poem is a call to action, since his interest and her beauty may both be short-lived. (p. 3)

Instead of focusing on this aspect of the man's desire, Marna instead chose to focus on the maiden or the object of desire. 'I wanted to focus on the shyness of the lady who also does not know how beautiful she is'. Miller (2000) states that:

Waller reveals that the woman is shy; she's 'young/and shuns to have her graces spied.' Yet, such charm will be wasted if it remains cloistered. The strongest admonition regarding the fragility of beauty arises in stanza 2, when the speaker likens her to a rose that blooms in an uninhabited desert and then dies 'uncommended'. (p. 3)

The fragility of beauty as described by Miller is evident in Marna's depiction of a woman who hides behind her own reflection. Marna describes her as 'she stands behind the window; one can only see her reflection, she stays hidden and almost becomes incorporeal or intangible'.

\section{Seeing beyond the surface: The evolution of idealised love}

Even though Jean Lampen was unfamiliar with the music and poetry, she was intrigued in particular by the music of Robert Schumann and Johannes Brahms. After listening to recordings by Karita Matilla ${ }^{12}$ she chose the following four art songs:

- Widmung Op. 25, No.1 R. Schumann (1810-1856)

- Du bist wie eine Blume Op. 25, No. 24

- Meine Liebe is grün wie der Fliederbusch Op. 63, No. 5 J. Brahms (1833-1897)

- Von ewiger Liebe Op. 43, No.1

12.Karita Mattila: Wild Rose (recording): Ondine. 1998. 
All four songs are powerful declarations of passionate love. The poetry is both bold and tender and conveys an idealised romance, which Jean experienced as a yearning for an 'otherworldly' love. Jean is a self-proclaimed minimalist and when first viewing her works they might seem to some as simplistic and literal adaptations of key words in the text. It is upon further viewing and understanding of her process that the deeper even cynical nuances are revealed.

Jean's process began with an analysis of the text, where she discovered that she could create visual cohesion using birds and sound waves:

I definitely did not know what I was going to do, until I listened to the music and started working through the poetry. Then I made a brain chart/map where I extracted words from the poetry, like Nightingale ... it's a bird ... birds fly ... musical notes can also fly or soar ... so I deduce that this could be a metaphor for something. When exploring the other art songs, I also noticed that birds are mentioned and I immediately thought that there is a common theme which I could develop through the songs. So my process is finding words which trigger other words, also triggering metaphors or concepts I would like to convey in the art. On a good day I could write and find three related words stemming from this triggering process; on an exceptional day there are many more words and connotations.

Once it became clear how Jean connected the birds to the elements of Sehnsucht in the poetry (Figure 9), her personal experiences of longing for an idealised love became evident. She reflects that 'Birds are not something that you can hold on to, these are not birds in cages, they are flying [...] the context in which you place them already depicts something on a deeper level'.

Jean had been divorced for several years and she no longer experienced love in the way that the poets expressed themselves in these songs. As a performer my interpretation of these songs was positive and extremely romantic, but as an observer and/or researcher it was enlightening to experience Jean's interpretation of the subject matter:

It was not 'feel good' music to me. For my age, I am beyond that kind of naive love. For me it is almost too sentimental. I interpreted it on another level. It was not just simply love, it was almost a philosophy.

In her depiction (Figure 10) of Heinrich Heine's text, $D u$ bist Wie eine Blume, Jean's pragmatic philosophy of love also guided her starting point during her process. By placing charcoal on paper on top of a speaker while she played the

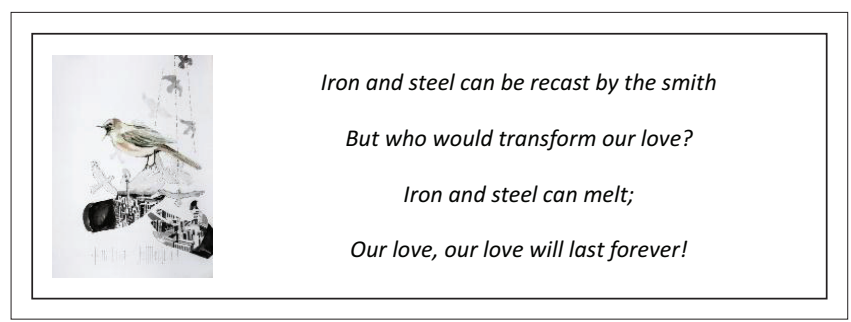

Source: Jean Lampen

FIGURE 9: Von Ewiger Liebe. song, the vibration of the music through the speaker guided the charcoal to their final point of rest as the song finished. Her minimalistic point of view was also portrayed in Figure 10 depicting the flower as described in Heine's text: 'Thou art so like a flower, so pure, and fair and kind'. This minimalism, evident in all her works, was the perfect vehicle to illustrate her own experiences of love, which entailed an evolution of idealised love to what she describes as reality:

I could have depicted a 'schmaltzy', gushy piece of work but instead I chose to create a weird charcoal flower which in fact does come from reality [...] I am a minimalist, so I go straight to the point of what I see. Leave out the fluff.

Jean's depicted cynicism and humour in Brahms's Von ewiger Liebe. In the opening lines of August Heinrich Hoffmann von Fallersleben's text, 'Dark, how dark it is in the forest and field, night has fallen; the world now is silent. Nowhere a light and nowhere smoke. Yes, now even the lark is silent', ${ }^{13}$ Jean depicts the lark with its beak wide open (Figure 9):

The Lark was silent but I depicted it with an open mouth. I am very cynical. My cynicism definitely came through with these four songs. It doesn't really manifest itself in my other works. This is obviously because of the subject material. Although these pieces came from a cynical point of view, [they] still depicted joy, appreciation and realism.

This joy and realism which Jean spoke of was finding love in herself through her art. In Schumann's Widmung (Figure 11), Friedrich Rückert's poem states: 'your gaze transfigures me; you raise me lovingly above myself, my good spirit, my better self!' In her depiction she showed a musician who was transfigured to his better self through music and by doing all the things he was passionate about.

To Jean one did not need romantic, idealised love to find fulfilment. She experienced this self-fulfilment in Brahm's Meine Liebe ist grün (Figure 12), specifically in Felix Schumann's text: 'My soul has the wings of a Nightingale'. 'This art song connected with Widmung in the way that I also wanted to depict a longing or desire to be my better self'.

By creating a visual representation of the elements of Sehnsucht in these songs, Jean confronted feelings about love in a way that she did not have the opportunity to do in

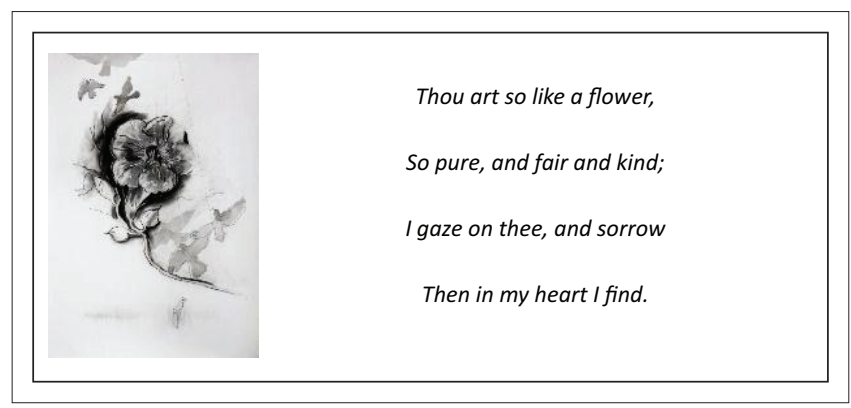

Source: Jean Lampen

FIGURE 10: Du bist wie eine Blume.

13.English translation by Leonard Lehrman (www.lieder.net: accessed on 02/01/2015). 


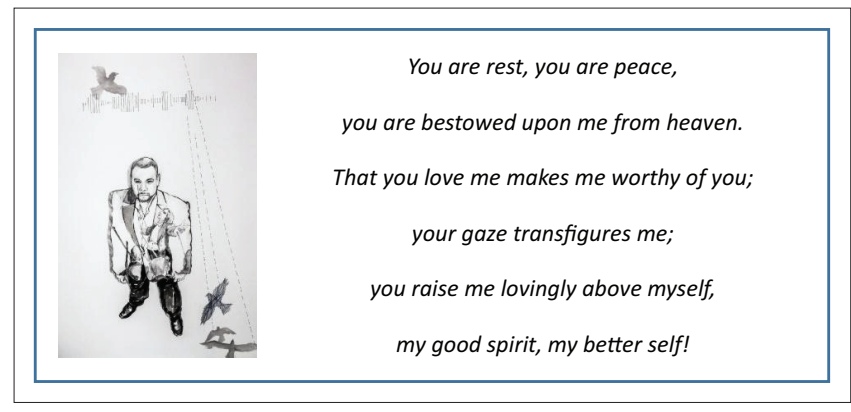

Source: Jean Lampen

FIGURE 11: Widmung.

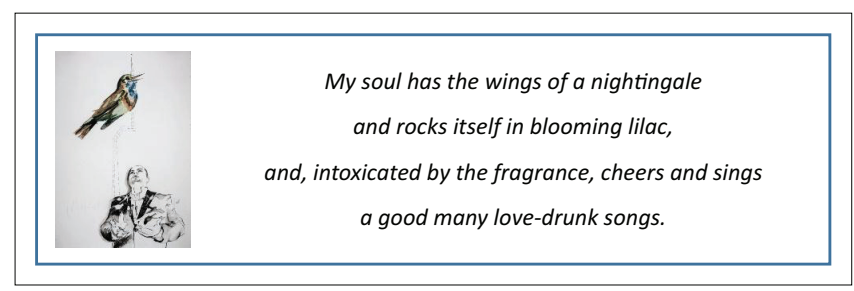

Source: Jean Lampen

FIGURE 12: Meine Liebe ist Grün.

previous works. The overtly romantic nature of the poetry might have guided another artist in a completely different direction, but it was the music of Schumann and Brahms together with Jean's minimalistic aesthetic which ultimately materialised in her art:

The music is actually greater than the text. The words are almost fluff. The words were almost the vehicle to bring life to the music. I may have used the words literally in my depictions, but it was on another level saying something with significantly more meaning than what is superficially evident.

\section{Depictions of Wanderlust portrayed through found objects}

I am homesick for a place I am not sure even exists. One where my heart is full and my soul is understood ... (Anonymous)

This quotation which Eljana van der Merwe remembered seeing somewhere in the past inspired her not only during this project but also during her life so far. This is why she was immediately drawn to Antonin Dvorak's Gypsy Songs (Cigánské melodie) Op. 55, which includes the following seven songs:

- My song sounds of love (Ma pisen zas mi laskou zni)

- Hah, how my triangle ringing (Aj, kterak trojhranec muj)

- The forest is quiet all around (A les je tichy kolem kol)

- Songs my mother taught me (Kdyz mne stara matka)

- The string is tuned (Struna naladena)

- Wide sleeves (Siroke rukavy)

- Give a hawk a cage (Dejte klec jestrabu).

This song cycle is a musical setting of the first part of a collection of poems by Adolf Heyduk entitled Gypsy Melodies. Of her whole experience while working on these visual representations Eljana writes:
Dvorak's Gypsy Songs were at times soothing like a homecoming song and at other times they stirred up urges of restlessness inspiring a strong desire to lead the feet in the direction of the unknown.

Eljana had preconceived notions of what her interpretation of the songs would be because of her previous encounters with the gypsy lifestyle. Before listening to the recordings of Anne Sofie von Otter's interpretation of the Gypsy Songs ${ }^{14}$ Eljana already decided to transfer the elements of Sehnsucht (specifically Wanderlust) to visual art. However, after reading the texts and listening to the music, she knew immediately that she would have to abandon her initial plan to visualise these songs:

I assumed that the theme of my works would reference what I interpreted as the typical bohemian gypsy style: a wild and free one. As soon as I listened to the rich music carefully and analysed the text, I could not have felt more removed from my initial idea (unless I deliberately wanted to exploit the commercial sense of the gypsy interpretation), but Dvorak is far from commercial or frivolous in that way. I had to dig much deeper to interpret an honest sense of the works.

Before embarking on this musical-visual amalgamation, Eljana had just returned from Mexico where she showcased a travelling exhibition called 'Wanderlust'. She thought it would be possible to adapt previous works from her Mexican visit to incorporate the elements of Sehnsucht which lent themselves to the feelings of Wanderlust: the strong desire to travel and explore. But Heyduk's and Dvorak's presentation of the feelings of wanderlust was completely different:

They [the poems] are characteristic for their fervent expression and emphasis on the bond between man and nature, on man's elemental need for music, and on freedom as something to be valued above all else. ${ }^{15}$

Two elements of Sehnsucht feature prominently in these songs: nostalgia and longing for freedom. Eljana's visual depiction of these elements of Sehnsucht was unique and again very different to that of the other artists. Instead of painting in her preferred medium of oil on canvas, Eljana sourced various materials which she felt told a story complementing the feelings and nostalgia conveyed in Heyduk's text and Dvorak's music:

I sourced 'found objects' to enhance the nature of a traveller's journey and the legacy that lives on. The untold journeys hiding in each of the carefully sourced items triggered nostalgia and awakened a longing in me for something or someplace I did not know [...] like a driftwood adventure, or the heat of a burning forest found in the final remains of the ruins and it is slowly smouldering in the aftermath [...] or the metal discs that once were part of the astronomical engineering works that focused the eye on the marvels of galaxies and promises of explorations beyond.

Eljana used these found objects as part of her visualisation of Sehnsucht in each art song:

14.Anne Sofie von Otter. Folksongs (recording): Deutsche Grammophon. 2000 15.http://www.antonin-dvorak.cz/en/gypsy-songs (accessed on 08/03/2016). 
The first song, with its use of an 'exotic' Gypsy scale and its tender, Schubertian shift from minor to major for the middle verse, is typical of the set in its mingled joy and soulful yearning. (Wigmore 2004)

Presented with the German and English translation ${ }^{16}$ of the original Czech text by Emily Ezust and Gayle Royko Heuser, respectively, Eljana isolated the words 'Wanderlust' and 'my feet roam distant lands' to serve as her inspiration for her first piece (Figure 13):

I recalled a specific day in the city of Puebla when I photographed an anonymous elderly woman along the way. She looked so fine, so well balanced on her stilettos on the cobblestone sidewalk. I had no idea about her, her journey or her destination - I was drawn to the secrecy of this stranger. I sensed a romantic undertone in the music and associated that mood with the strong colour of the woman's dress. The rhythm of her stroll sounded of love to me as mentioned in Heyduk's text.

Eljana painted this image on wood from a dismantled birdfeeder. She also used this bird-feeder as the surface for her paintings (Figure 14) of the fifth song, Struna naladèna (The string is tuned), capturing the highly energetic nature of the poetry and music by the Dutch signs 'Heen' and 'Weer', meaning 'to go back and forth'. She captured these images in Leiden in the Netherlands.

Eljana used three metal discs and a burnt piece of wood as her canvases for the second and third songs, respectively. She captured the nostalgia in the second song, conveyed by Dvorak's brisk tempo, by portraying it across three separate pieces. 'The music is fast and having to view a fragmented work accentuates and compliments the jerky rhythm'. In Dvorak's third song he sets Heyduk's

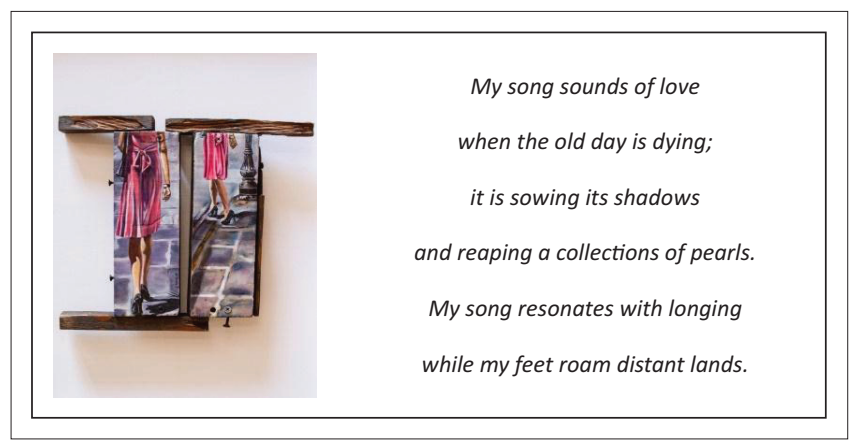

Source: Eljana van der Merwe

FIGURE 13: 'My Song Sounds of Love'.

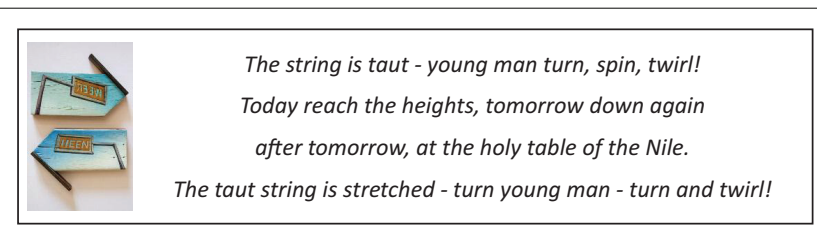

Source: Eljana van der Merwe

FIGURE 14: 'The String Is Tuned'.

16.Translations were found on The LiederNet Archive (www.lieder.net/lieder accessed on $02 / 01 / 2015$ ) and used with permission. lines: ${ }^{17}$ 'The forest is quiet all around; only the heart is disturbing the peace. As if black smoke is flowing, tears flow down my cheeks and so they dry'. Eljana drew inspiration from the words 'black smoke' and painted a forest scene (Figure 15) while trying to convey the hopeful sentiments of the final verse of the poetry:

I chose a burnt piece of wood to work on. It was the remains of roof beams from a burnt-down house. I detected a sombre mood in the music and chose a quiet forest scene I photographed in the Netherlands. As the lyrics have an optimistic end, the bridge resembles hope.

Dvorak's fourth song, translated as 'Songs my mother taught me', (Figure 16) is arguably the best known song of the cycle. Dvorak employs an unusual rhythmic structure which, together with Heyduk's text, conjures nostalgic images of a mother's love for her child. ${ }^{18}$ Eljana depicted this nostalgia by painting images of vintage toys on old discs she sourced from an observatory:

I chose to paint vintage toys I photographed in the shop windows of The Hague and Mexico, as they remind me of old mothers. These toys are timeless and transport me to a state of oblivion.

While the first five songs highlighted nostalgia in the music and poetry, the last two songs awaken the intense longing for a Gypsy's freedom. 'Nostalgia is banished in the next two songs, which celebrate the carefree Gypsy life in bold, leaping and unmistakably Czech - dance rhythms' (Wigmore 2004). In the sixth song, Široké rukávy [Wide sleeves], Eljana depicted this yearning for freedom as clothing blowing in the wind painted on a piece of driftwood:

I see a humble washing line with white laundry blown by the breeze - free from constraints and transparent in nature. I carried the surface for the painting with me all the way from

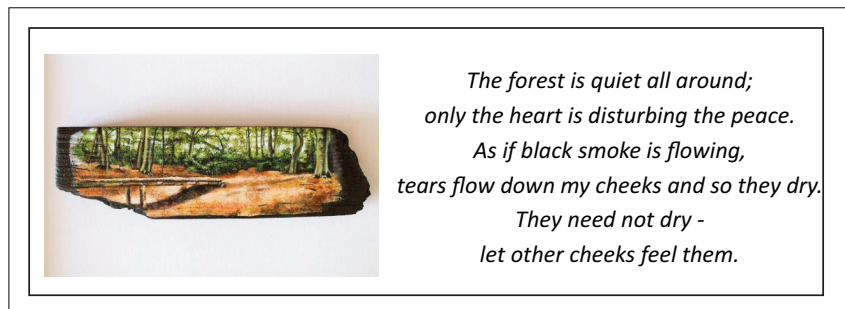

Source: Eljana van der Merwe

FIGURE 15: 'The Forest Is Quiet All Around'.

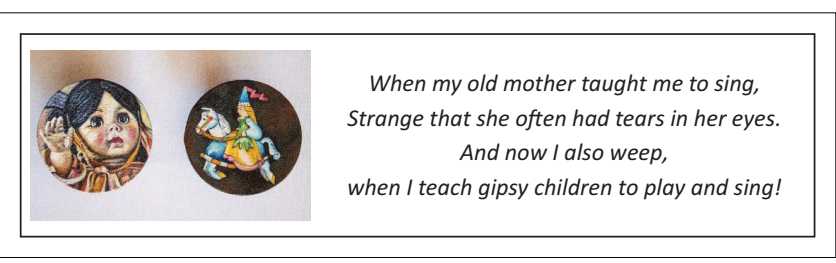

Source: Eljana van der Merwe

FIGURE 16: 'Songs My Mother Taught Me'.

17.'A les je tichý kolem kol, jen srdce mír ten ruší, a černý kouř, jenž spěchá v dol, mé slze v lících, mé slze suší' (original Czech).

18.'its haunting, nostalgic tune and subtle pull between the melody (in 2/4 rhythm) and the syncopated $6 / 8$ accompaniment has enabled it to weather any number of sentimental performances and dubious arrangements' (Wigmore 2004). 
Mozambique. Nothing could be more liberated than a piece of driftwood.

Eljana also captured this longing for freedom in the final song through symbolic images representing freedom, painted on the beam of a roof.

\section{Commonalities and differences}

During the course of this project, there were some commonalities and differences in the approach and process shared by the artists. While working on this project the artists became aware of a fresh understanding of their process.

Understanding Sehnsucht leads to a further awareness and development of the creative process

As a result of our initial conversations during our meetings and studying the music and poetry, the artists better understood the essence of Sehnsucht. Marna only realised after identifying the nostalgia and melancholy in the music and poetry that she had tried to capture this feeling in her paintings in the past. In essence the understanding and awareness of Sehnsucht informed her creative process more clearly. Identifying and understanding Sehnsucht also lead the artists to super-impose their personal lived experiences on the meaning which they ascribed through the music and poetry. This resulted in a development of their creative process.

Creating a work of art from music and poetry served as a magnifying lens which the artists used to intensify the emotions which they wanted to illustrate in their work. While Kevin du Plessis was able to use his works as an outlet for new, unexplored feelings of sexuality, Jean Lampen confronted feelings of love as experienced by a single woman and mother who is divorced. She had never known that her cynicism about love was so strong until she participated in this project. The artists also incorporated their own interests into their work. Marna's affinity for a Victorian aesthetic and melancholy propelled her inspiration together with the text and music. Eljana's self-proclaimed gypsy lifestyle and her feelings of Wanderlust were the perfect fit for her portrayal of Sehnsucht in the poetry of Heyduk and music of Dvorak.

\section{Music $v$ text: Varying degrees of inspiration throughout the creative process}

None of the art works was a merely literal representation of the text, but rather an intense personal and emotional portrayal by the artists of the essence of the music and poetry. While all of the artists studied the poetry and music in depth prior to beginning their work, their processes did differ significantly. Katz (1989) refers to music as being nonreferential:

it pictures, describes or symbolises none of the actions, persons, passions and concepts ordinarily associated with human experience [...] there is no reason to expect that our emotional experience of it should be referential. (p. 180)
The artists mentioned that the music significantly influenced the conception of their ideas and final works, but with the exception of Kevin du Plessis to a certain degree, the artists were unable to verbalise precisely how they were influenced directly by the music. This could be attributed to the fact that none of the artists were musicians and did not possess the necessary vocabulary to describe the melodies, harmonies, tonal colour and rhythm. Another reason could be the nonreferential nature of music as described by Katz (1989). Marna de Wet, Jean Lampen and Eljana van der Merwe used word associations to varying degrees; nonetheless the association of words and the emotions which they felt in the music led to their eventual depictions of Sehnsucht.

While Kevin du Plessis also studied the texts, he actively incorporated the music during his photo sessions, thus leaving creative space for the music, including the harmonies, phrasing, rhythms and emotional intensity of the singing voice, to guide him in capturing the ultimate frame used in the art.

\section{Symbolism and colour used to ascribe meaning to Sehnsucht}

The artists used symbolism and colour to varying degrees in all of their works. Jean Lampen used birds not only as a unifying theme in her works, but also to represent love which was not smothered but rather free. The imagery which she used to fill in the person in her charcoal drawings symbolised their better selves. Although the poetry spoke of a yearning for a passionate love, this love was not represented in her work by another person, but rather other passions in the lives and careers of the subjects in her works. Although her work was mostly black and white, her subtle use of watercolours used selectively for some of the birds accentuated her idea of love through minimalistic means.

Kevin used a house with its single occupant to emphasise the loneliness and longing he interpreted in the texts and music. This longing was further represented by places inside the house, such as the bedroom (the longing for love), the floor (the longing for emotional relief), the door (the longing for a deceased lover) and the window (longing with hope for new beginnings). The colour and movement of the white, grey and black sheets and the technical use of grey scale added symbolic meaning to his interpretation. Although he did not see his works as self-portraits, Kevin was the model for his own photographs depicting homoerotic love, longing, broken-heartedness and the yearning for things past or out of reach.

Marna de Wet's use of symbolism was evident in her oil paintings on canvas. Her use of the bed and luxurious sheets which were already slept in portrayed the longing for love. The combination of the Victorian silhouette of the boy and the use of colour to depict the moorland was instrumental in her portrayal of nostalgia for a home long gone. Her sombre use of colour also contributed to her interpretation of melancholy in the music of Roger Quilter. 
While Eljana van der Merwe incorporated vibrant colour throughout her work, the symbolic use of colour was most evident in her first piece, where the rich tones of purples, reds and pinks represented her interpretation of what the sounds of love would be like. She used sourced objects with emotional significance for her to complement the feelings of Wanderlust, nostalgia and yearning for freedom present in the poetry and music. These included a dismantled bird-feeder, metal discs from an observatory, a burnt piece of wood, a piece of wood from a roof beam and a piece of driftwood from Mozambique.

\section{Conclusion}

This research has granted the reader access to the experiences shared by these four artists during their process of portraying the elements of Sehnsucht in the music of Vaughan Williams, Quilter, Dvorak, Schumann, Strauss and Brahms. It could be interpreted that when presented with both text and music, visual artists are drawn to the text because of its referential nature. However, it is clear that the music (although not always describable) remains an intrinsic part of their process and inspiration. Future research is recommended and necessary to further understand these experiences. Because other artists' interpretation and experiences of these specific art songs would be completely different, the outcomes of future research might differ significantly from, or illustrate commonalities with, the experiences of these four artists. Also, the oeuvre of the art song is limitless, with new works being composed regularly; hence multimedia projects like this one would always inspire musicians and visual artists to collaborate and produce work crossing traditional trans-disciplinary boundaries.

\section{Acknowledgement Competing interest}

The author declares that he has no financial or personal relationship(s) which may have inappropriately influenced him in writing this article.

\section{References}

Adler, G., 1885, 'Umfang, Methode und Ziel der Musikwissenschaft', Vierteljahrsschrift für Musikwissenschaft 1, Chapter 2, p. 5.

Auping, M., Butler, C., Hecker, J., Biesenbach, K. \& Kentridge, W., 2009, 'Sarastro and his master's voice', in M. Rosenthal, (ed.), William Kentridge: Five themes, pp. 170-193, Yale University Press, New Haven, CT.

Beller-McKenna, D., 2010, 'Between Sehnsucht and nostalgia: Brahms's Lieder und Romanzen for women's chorus, op. 44', Ars lyrica: Journal of the Lyrica Society for Romanzen for women's chorus, op. 44', Ars lyrica: Journal of the Lyrica Society for
Word-Music Relations. IXX (2010): [Felix Mendelssohn and Johannes Brahms Issue] 19, 129-152.

Burn, A., 2003, Songs of travel, viewed 1 March 2016, from www. Hyperion-records. co.uk: http://www.hyperion-records.co.uk/dw.asp?dc=W4429_67378

Byrnes, S., 2007, 'The colour of music', New Statesman 136(4869), 42-43.

Canisius, C., 1992, Beethoven: Sehnsucht und Unruhe in der Musik, Piper, München.

Clark, R., 2014, 'Aspects of national identity in the art songs of Ralph Vaghan Williams before the great war', PhD Dissertation, University of Illinois at UrbanaChampaign, Urbana, IL.

Decker, D., 1989, 'Baudouin Oosterlynck', Artefactum 31, 16-18.

De Duve, T., 2013, 'Don't shoot the messenger', Artforum International 52(3), 264-312.

Doherty, W., 2013, “"Ein unregelmäßiges Duett": The duet settings of "Nur wer die Sehnsucht kennt"', Music: Function and value-Proceedings of the 11th International Congress on Musical Signification: Cracow, Akademia Muzyczna w Krakowie, Kraków, September 27-October 2, 2010, vol. 2, pp. 978-983.

Doherty, W., 2014, 'Semiosis in a Schubert Song', Chinese Semiotic Studies 10(2), 353-362.
Dvorak, A., Grainger, P. \& Hahn, R., (Composers)., 2000, Folksongs. [A. S. Otter, \& B. Forsberg, Performers] Deutsche Grammophon.

Forbes, E., 1972, 'Nur wer die Sehnsucht kennt: An example of a Goethe lyric set to music', in L. Berman \& E. Forbes (eds.), Words and music: The scholar's view A medley of problems and solutions compiled in honor of A. Tillman Merritt by sundry hands, pp. 59-82, Department of Music, Harvard University, Cambridge, MA

Gilliams, B. \& Youmens, C., n.d., (Oxford University Press), viewed 20 January 2016, from Grove Music Online. Oxford Music Online: http://www.oxfordmusiconline. com/subscriber/article/grove/music/40117pg8

Gottdang, A., 2006, 'Beethoven in the paint-box: Connections between landscape painting and music around 1850', Musicologica austriaca: Jahresschrift der Österreichischen Gesellschaft für Musikwissenschaft 25, 33-53.

Hallmark, R., 2003, Robert Louis Stevenson, Ralph Vaughan Williams and their Songs of Travel, Ashgate, Aldershot, Hants.

Hambrick, J., n.d., www.allmusic.com., viewed 7 March 2016, from http://www. allmusic.com/composition $/ \mathrm{c} \% \mathrm{C} 3 \% \mathrm{~A} 4$ cilie-wenn-du-es-w\% $\% 3 \%$ BCsstest-songfor-voice-piano-or-orchestra-op-27-2-trv-170-2-mc0002665732

Jewanski, J., 2011, 'Morton Feldman's compositions influenced by painting: The problem of concretization', in Wie Bilder klingen. Series: Neue Innsbrucker Beiträge zur Musikwissenschaft, pp. 169-181, Lit Verlag, Vienna.

Johnson, K., 2009, Modernity met with hope and despair, The New York Times, New York.

Jung-Kaiser, U., 2009, 'Wer weiß, was ich leide? Beethovens Sehnsucht', 1808: Ein Jahr mit Beethoven. Series: Wegzeichen Musik 3, 121-175.

Juslin, P., Liljeström, S., Västfjäll, D., Barradas, G. \& Silva, A., 2008, 'An experience sampling study of emotional reactions to music: Listener, music, and situation', Emotion 8(5), 668-683. http://dx.doi.org/10.1037/a0013505

Katz, R., 1989, Contemplating music, source readings in the aesthetics of music: Aesthetics in music no.5. 2. Pendragon Press, New York.

Kennedy, M., (ed.), n.d., (Oxford University Press) The Oxford Dictionary of Music, 2nd edn. rev. edn., Oxford Music Online, viewed 20 January 2016, from http://www. oxfordmusiconline.com/subscriber/article/opr/t237/e3246

Kennedy, M. (ed.), n.d., (Oxford University Press), The Oxford Dictionary of Music, 2nd edn. rev. edn., Oxford Music Online: The Oxford Dictionary of Music, 2 nd edn., rev. edn., Oxford Music Online, viewed 20 January 2016, from http://www. oxfordmusiconline.com/subscriber/article/grove/music/42507

Kotter-Grühn, D., Wiest, M., Zurek, P. \& Scheibe, S., 2009, 'What is it we are longing for? Psychological and demographic factors influencing the contents of Sehnsucht (life longings)', Journal of Research in Personality 43(3), 428-437. http://dx.doi. org/10.1016/j.jrp.2009.01.012

Langfield, V., n.d., (Oxford University Press) from Grove Music Online. Oxford Music Online, viewed 20 January 2016, from http://www.oxfordmusiconline.com/ subscriber/article/grove/music/22702

Larsen, J., 1969, 'Zu Schuberts Vertonung des Liedes Nur wer die Sehnsucht kennt', in Musa - Mens - Musici: Im Gedenken an Walther Vetter, pp. 227-281, VEB Deutscher Verlag für Musik, Leipzig.

Larson, M., 2001, 'Text/music relations in Ralph Vaughan Williams' songs of travel: An interpretive guide', DMA Thesis, Arizona State University.

Leman, M., 2010, 'Music research at the cross-roads of innovation: Tendencies, perspectives and opportunities of a transdisciplinary approach', in S.D. Pena (ed.), perspectives and opportunities of a transdisciplinary approach', in S.D. Pena (ed.),
Themes in transdisciplinary research, pp. 64-89, Editora Universidade Federal de Themes in transdisciplinary res
Minas Gerais, Ghent, Belgium.

Lewis, C.S., (1949) [revised 1980], The weight of glory and other address, Harper Collins Publishers, New York.

Malvano, A., 2003, Voci da lontano: Robert Schumann e l'arte della citazione, EDT, Torino.

Mazzaro, M., 2016, 'Noteworthy and now', Opera News 80(9), 6.

McClain, M., 1984, 'Goethe and music: Nur wer die Sehnsucht kennt', in Johann Wolfgang von Goethe: One hundred and fifty years of continuing vitality, pp. 201-227, Texas Technical University, Lubbock, TX.

Miller, P., 2002, 'Go, lovely rose', in Masterplots II: Poetry, rev. ed., pp. 1-3, Literary Reference Center, EBSCOhost, viewed 1 March 2016, from http://eds.b.ebscohost. com.nwulib.nwu.ac.za/ehost/detail/detail?sid=0d9e31b9-8647-444d-aa0692976 ede0bf3\%40sessionmgr120\&vid=65\&hid=114\&bdata=\#AN=103331POE15 $120351000105 \& \mathrm{db}=\mathrm{Ifh}$

Mohr, M., 2000, 'Digital Salon Artists' Statements', Leonardo 33(5), 441, viewed 1 March 2016, from www.poetryfoundation.org: http://www.poetryfoundation. org/bio/alfred-tennyson

Olthafer, R., 2006, 'Goethe's Mignon: Settings of Nur wer die Sehnsucht kennt', Doctoral dissertation, DMA from University of Wisconsin, Madison.

Orrey, L. \& Warrack, J., n.d., (A. Latham, Editor, \& Oxford University Press), Grove Music Online. Oxford Music Online, viewed 20 January 2016, from http://www. oxfordmusiconline.com/subscriber/article/opr/t114/e3971

Oteri, F., 2005, Music and art beneath the surface, viewed 3 March 2015, from http:// www.americancomposers.org:http://www.americancomposers.org/archive/200405-season/art-surface-essay-htm/

Petrauskaite, D., 2012, 'Characteristics and reflections of nostalgia in the Lithuanian music of the twentieth century', in Between nostalgia, utopia, and realities. Series: Musicological studies: Proceedings, No. 4, pp. 289-297, Fakultet Muzičke Umetnosti, Beograd, Yugoslavia.

Quilter, R., (Composer)., 2004, Silent Noon. [B. Terfel, \& M. Martineau, Performers] Deutsche Grammophon. 
Reichert, S., 1994, 'Unendliche Sehnsucht: The concept of longing in German Romantic narrative and song', Doctoral dissertation, PhD from Yale University.

Reid, K., Flowers, P. \& Larkin, M., 2005, 'Exploring lived experiences', The Psychologist $8(1), 20-23$

Rogers, F.R. \& Rogers, M., 1985, Painting and poetry: Form, metaphor, and the language of literature, Associated University Presses, Cranbury, NJ.

Rummenhöller, P., 1999, “'Nur wer die Sehnsucht kennt...”: Verliebtheit als Motiv in Musik, Literatur und Kunst', Musik Und Unterricht: Zeitschrift Für Musikpädagogik 10(54), 4-7.

Schumann, R., Brahms, J., Schubert, F. \& Beethoven, L.V., (Composers)., 1998, Wild Rose [K. Mattila, \& I. Ranta, Performers] Ondine.

Smith, J., Flowers, P. \& Larkin, M., 2009, Interpretive phenomenological analysis, Sage, London.

Strauss, R., (Composer)., 1983, Four Last Songs, Six Orchestral Songs, [J. Norman Performer, \& K. Masur, Conductor] Decca.
Tennyson, A., n.d., www.poetryfoundation.org., viewed 10 April 2016, from https:// www.poetryfoundation.org/poems-and-poets/poets/detail/alfred-tennyson\#poet

Urmoneit, S., 2002, 'Mignons Sehnsucht: Versuch über Goethe, Zelter und Schubert', Schubert: Perspektiven 2(1), 22-56.

Vergo, P., 2010, The music of painting: Music, modernism and the visual arts from the Romantics to John Cage, Phaidon, London, England.

Wharton, M., 1998, Visual art and poetry in the songs of Francis Poulenc, DMA from University of lowa, lowa City, IA.

Wigmore, R., 2004, Antonin Dvořák and the songs of his time (essays from the program booklet), Salzburg Festival, viewed 10 April 2016, from http:// hampsongfoundation.org/antonin-dvorak-and-the-songs-of-his-time-essay/

Williams, V., (Composer)., 1995, The Vagabond. [B. Terfel, \& M. Martineau, Performers] Deutsche Grammophon.

www.southafrica.info. n.d., viewed 10 April 2016, from http://www.southafrica.info/ about/arts/south-african-grammys-2015-091215.htm\#.V_OdxMliNRA 